

UNIVERSITY OF CALIFORNIA

Division of Agriculture and Natural Resources http://anrcatalog.ucdavis.edu

\title{
Genetic Engineering and Fish
}

ALISON L. VAN EENENNAAM, Extension Specialist, Animal Genomics and Biotechnology, Department of Animal Science, University of California, Davis

\section{What is the current status of genetically engineered fish?}

The first genetically engineered fish were produced 20 years ago, and since that time over 35 species have been genetically engineered. Currently, no genetically engineered fish has been approved for food production in the United States. Compared with mammals, fish offer important advantages for genetic engineering because of the large number of eggs laid per female, out-of-mother fertilization and embryonic development in most species, lower probability of carrying human pathogens, and the fact that aquaculture is a rapidly expanding market. Many countries, including China, Cuba, India, Korea, the Philippines, and Thailand, have active research programs in the area of genetically engineered fish. Ironically, in addition to being the taxonomic group with the most genetically engineered species, aquatic organisms are also one of the groups most likely to present environmental concerns if accidentally released into the environment. Unlike most other agricultural species, fish are difficult to contain and highly mobile, and they can easily become feral and invade native ecosystems (National Research Council 2002).

\section{What is a genetically engineered fish?}

Genetically engineered (also called transgenic) fish are those that carry and transmit one or more copies of a recombinant DNA sequence (i.e., a DNA sequence produced in a laboratory using in vitro techniques). Because genetic engineering is defined by the technology that is used to create and transfer the DNA sequence, and not the source species of the donor DNA, even fish that are engineered with DNA derived entirely from fish species are considered to be genetically engineered. Currently, no genetically engineered fish has been approved for food production in the United States. To date only one company, AquaBounty, has publicly announced that it has requested FDA approval to market a genetically engineered food animal, a growthenhanced Atlantic salmon that is capable of growing 4 to 6 times faster (but not larger) than standard salmon grown under the same conditions.

\section{What are the science-based concerns associated with genetically engineered fish?}

The greatest science-based concerns associated with genetically engineered fish are those related to their inadvertent release or escape. Concerns range from interbreeding with native fish populations to ecosystem effects resulting from heightened competition for food and prey species. There is, in principle, no difference between the types of concerns associated with the escape of genetically engineered fish and those related to the escape of fish that differ from native populations in some other way, such as captively bred populations (Lynch and O'Hely 2001). Ecological risk assessment requires an evaluation of the fitness of the genetically engineered fish relative to non-genetically engineered fish in the receiving population in order to determine the probability that the transgene will spread into the native population. Ecological impacts are the result of the characteristics of the organism, regardless of whether the organism acquired those characteristics through natural selection, artificial selection, or genetic engineering. The presence of genetically engineered fish does not a priori have a negative effect on native populations. If genetically engineered fish are ill-suited to an environment or are physically unable to survive outside of containment, they may pose little risk to the native ecosystems. Regulators apply a scientifically derived, 
risk-based framework to assess the ecological risks involved with each transgene, species, and receiving ecosystem combination on a case-by-case basis. Risks will be quite specific to the gene, species, and site in question, and simple generalizations concerning the risks (and benefits) of genetically engineered fish are not scientifically meaningful.

\section{Can containment be used to isolate genetically engineered fish?}

Commercialization of genetically engineered fish will likely depend on the development of effective containment strategies. If genetically engineered fish are adequately contained, they pose little risk to native populations. The NRC recommended the simultaneous use of multiple containment strategies for genetically engineered fish (National Research Council 2004). Physical containment is an obvious first line of defense to prevent the escape of genetically engineered fish. Examples of such measures may include building facilities on land or in locations removed from native populations, or ensuring that water chemistry (temperature, $\mathrm{pH}$, salinity, and concentrations of certain chemicals) is lethal to one or more life stages of the genetically engineered fish, such as treating effluent water to prevent the release of viable gametes or fry. Biological containment or bioconfinement approaches such as sterilization are also being developed.

\section{Who is in charge of regulating genetically engineered fish in the United States?}

In the United States, the use of genetically engineered fish is federally regulated under the Food, Drug, and Cosmetics Act. Under this statute, the U.S. Food and Drug Administration's Center for Veterinary Medicine (CVM) asserts primary jurisdiction over genetically engineered animals. Genetically engineered animals for production fall under CVM regulation as new animal drugs. Investigational applications are filed requesting approval for gene-based modifications, and after providing adequate safety data, the sponsor may request approval for these animals to be used for food or for processing into animal feed components.

In addition to ensuring food safety, the FDA also evaluates environmental risks posed by genetically engineered animals as directed by the National Environmental Policy Act (NEPA). Under NEPA, federal agencies are obligated to cooperate with other involved federal agencies. In the case of the AquaBounty genetically engineered salmon, this cooperation includes involvement of the U.S. Fish and Wildlife Service and the National Marine Fisheries Service in the development of a scientifically based environmental risk assessment.

\section{Are there additional California regulations associated with genetically engineered fish?}

In California, a permit is required to import, transport, possess, rear, or conduct research on genetically engineered fish. Such fish must be kept in a closed-water system or one that does not allow the inadvertent release of live fish, and access to facilities containing genetically engineered fish must be restricted. The California Fish and Game Commission holds a public hearing for each permit application to ensure that any permit granted is in the public's best interest.

Additional California legislation related to genetically engineered fish was introduced in the 2003 legislative session as SB 245. This bill contains in part the following language: "In the waters of the Pacific Ocean that are regulated by this state, it is unlawful to spawn, incubate, or cultivate any species of finfish belonging to the family Salmonidae, genetically engineered fish species, or any exotic species of finfish" (California State Senate 2003). The bill exempts native California Salmonidae stocks that are propagated and cultured for release into ocean waters for the purpose of recovery, restoration, or enhancement of California's native salmon and steelhead trout populations. This legislation effectively precludes non-native Salmonidae coastal net-pen 
aquaculture, genetically engineered or otherwise, in the ocean from 0 to 3 miles (4.8 $\mathrm{km}$ ) off California's shore.

\section{What about GloFish?}

In 2003, a genetically engineered zebra danio that produces a red fluorescent protein became commercially available in most U.S. pet shops. The zebra danio is a small aquarium species that has never survived outside captivity in the United States, despite repeated intentional and accidental releases. The FDA determined not to formally regulate GloFish. The rationale for this decision was explained in the following FDA statement: "Because tropical aquarium fish are not used for food purposes, they pose no threat to the food supply. There is no evidence that these genetically engineered zebra danio fish pose any more threat to the environment than their unmodified counterparts which have long been widely sold in the United States. In the absence of a clear risk to the public health, the FDA finds no reason to regulate these particular fish" (U.S. Food and Drug Administration 2003). This lack of formal regulation was seen by some as a dangerous precedent for the regulation of genetically engineered animals. Despite the FDA's decision not to regulate the commercial sale of GloFish, it is not currently available from pet stores in California as a result of California Fish and Game regulations requiring a permit to import, transport, possess, or rear genetically modified fish in onshore water systems.

\section{Will consumers accept genetically engineered fish?}

Ultimately, it is the marketplace, and not science, that decides the fate of new technologies and acceptability of certain risks. Food retailers and even farmers may be unwilling to stock genetically engineered fish and risk having their market become the target of an organized antibiotech campaign (Aerni 2004). Such a scenario occurred in Europe, where activist campaigns targeted retailers stocking labeled genetically engineered food products, and attempts to differentiate brands resulted in the removal of these products from supermarket shelves altogether (Kalaitzandonakes and Bijman 2003). Despite strong public support for medical applications of genetic engineering, there is less public support for agricultural biotechnology. However, market response and consumer behavior may differ markedly between affluent Western countries and developing countries. Even if genetically engineered fish are approved by the FDA in the United States, it will likely be activist, food retailer, and consumer response in the marketplace that will ultimately decide whether genetically engineered food fish will sink or swim.

\section{PERSPECTIVE}

No genetically engineered fish have yet been approved for food production in the United States. To date, the only request for FDA market approval of a genetically engineered food fish has been for a growth-enhanced Atlantic salmon. In addition to considering food safety, the FDA evaluates the ecological risks involved with each genetically engineered DNA, species, and receiving ecosystem combination on a case-by-case basis. The greatest science-based concerns associated with genetically engineered fish are those related to their inadvertent release or escape. Commercialization of genetically engineered fish likely will depend on the development of effective containment strategies. California has developed regulations prohibiting genetically engineered fish from the ocean 0 to 3 miles $(4.8 \mathrm{~km}$ ) off California's shore, and a permit is required to import, transport, possess, rear or conduct research on genetically engineered fish in California. Given these stringent state regulations, it seems unlikely that genetically engineered fish will be used in California agricultural production systems. 


\section{REFERENCES}

Aerni, P. 2004. Risk, regulation and innovation: The case of aquaculture and transgenic fish. Aquatic Science 66:327-341.

California State Senate. 2003. Senate Bill 245. Text available at the California State Senate Web site, http://info.sen.ca.gov/pub/03-04/bill/ sen/sb_0201-0250/sb_245_bill_20031012_chaptered.pdf

Kalaitzandonakes, N., and J. Bijman. 2003. Who is driving biotechnology acceptance? Nature Biotechnology 21:366-369.

Lynch, M., and M. O'Hely. 2001. Captive breeding and the genetic fitness of natural populations. Conservation Genetics 2:363-378.

National Research Council. 2002. Animal biotechnology: Science-based concerns. Washington, D.C.: National Academies Press.

- 2004. Biological confinement of genetically engineered organisms. Washington, D.C.: National Academy Press.

U.S. Food and Drug Administration. 2003. FDA statement regarding GloFish. Press release, December 9. U.S. FDA Web site, http://www.fda.gov/bbs/topics/NEWS/2003/NEW00994.html.

\section{FOR MORE INFORMATION}

To order or obtain printed ANR publications and other products, visit the ANR Communication Services online catalog at http://anrcatalog.ucdavis.edu. You can also place orders by mail, phone, or FAX, or request a printed catalog of our products from:

University of California

Agriculture and Natural Resources

Communication Services

6701 San Pablo Avenue, 2nd Floor

Oakland, California 94608-1239

Telephone: (800) 994-8849 or (510) 642-2431

FAX: (510) 643-5470

E-mail inquiries: danrcs@ucdavis.edu

An electronic version of this publication is available on the ANR Communication Services Web site at http://anrcatalog.ucdavis.edu.

Publication 8185

(C) 2005 by the Regents of the University of California, Division of Agriculture and Natural Resources. All rights reserved.

The University of California prohibits discrimination or harassment of any person on the basis of race, color, national origin, religion, sex, gender identity, pregnancy (including childbirth, and medical conditions related to pregnancy or childbirth), physical or mental disability, medical condition (cancer-related or genetic characteristics), ancestry, marital status, age, sexual orientation, citizenship, or status as a covered veteran (covered veterans are special disabled veterans, recently separated veterans, Vietnam era veterans, or any other veterans who served on active duty during a war or in a campaign or expedition for which a campaign badge has been authorized) in any of its programs or activities. University policy is intended to be consistent with the provisions of applicable State and Federal laws. 


\section{UC}

Inquiries regarding the University's nondiscrimination policies may be directed to the Affirmative Action/Staff Personnel Services Director, University of California, Agriculture and Natural Resources, 300 Lakeside Drive, 6th Floor, Oakland, CA 94612-3550 (510) 987-0096. For a free catalog of other publications, call (800) 994-8849. For help downloading this publication, call (530) 297-4445.

To simplify information, trade names of products have been used. No endorsement of named or illustrated products is intended, nor is criticism implied of similar products that are not mentioned or illustrated.

This publication has been anonymously peer reviewed for technical accuracy by University of California scientists and other qualified professionals. This review process was managed by the ANR Associate Editor for Animal, Avian, Aquaculture, and Veterinary Sciences.

pr-11/05-SB/CR

ISBN 978-1-60107-335-8 